https://doi.org/10.17816/MAJ191S1217-219

\title{
CYTOKINE PROFILE OF RAT BLOOD SERUM DURING EXPERIMENTAL BRONCHOPULMONARY INFLAMMATION AND IMMUNOMODULATOR ADMINISTRATION
}

\author{
E.V. Mokrenko ${ }^{1,2}$, P.D. Shabanov ${ }^{2}$ \\ ${ }^{1}$ C.M. Kirov Military Medical Academy, Saint Petersburg, Russia; \\ ${ }^{2}$ Irkutsk State Medical University, Irkutsk, Russia
}

\section{ЦИТОКИНОВЫЙ ПРОФИЛЬ СЫВОРОТКИ КРОВИ КРЫС ПРИ ЭКСПЕРИМЕНТАЛЬНОМ БРОНХОЛЕГОЧНОМ ВОСПАЛЕНИИ И ВВЕДЕНИИ ИММУНОМОДУЛЯТОРОВ}

\begin{abstract}
Е.В. Мокренко ${ }^{1,2}$, П.Д. Шабанов
${ }^{1}$ ФГБВОУ ВО «Военно-медицинская академия им. С.М. Кирова» МО РФ, Санкт-Петербург;

${ }^{2}$ ФГБОУ ВО «Иркутский государственный медицинский университет» МЗ РФ, Иркутск

mokrenko@newstom.ru

Experimental bronchopneumonia was modeled by administering turpentine to the trachea under ether anesthesia. After the operation, the solution of one of the studied immunomodulators was intraperitoneally administered to the animals for 5 days ( 1 time/day): polyoxidonium $-0.75 \mathrm{mg} / \mathrm{kg}$, trekrezan $25 \mathrm{mg} / \mathrm{kg}$ or metaprot $25 \mathrm{mg} / \mathrm{kg}$. After decapitation, the interleukin profile was determined in the blood using commercial

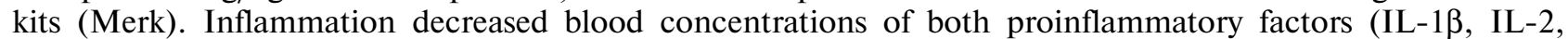
IL-12, INF- $\gamma$ and chemokine MCP-1), and anti-inflammatory (IL-4, IL-10) cytokines. At the same time, the levels of TNF $\alpha$ and IL-6, as well as the anti-inflammatory cytokine IL-13, increased. The introduction of immunomodulators, polyoxidonium, trekrezan or metaprot substantially normalized the level of pro- (IL-1 $\beta$, IL-2, IL-12 (p7), chemokine MCP-1, INF $\alpha$ ) and anti-inflammatory cytokines (IL-4, IL-10). The antiinflammatory effect of drugs is associated with the normalization of cytokine metabolism.
\end{abstract}

Keywords: bronchopneumonia; cytokines; immunomodulators; polyoxidonium; trekrezan; metaprot.

Экспериментальную бронхопневмонию моделировали введением скипидара в трахею под эфирным наркозом. После операции на протяжении 5 дней (1 раз/сут) животным внутрибрюшинно вводили раствор одного из исследуемых иммуномодуляторов: полиоксидония $-0,75$ мг/кг, трекрезана 25 мг/кг или метапрота 25 мг/кг. После декапитации в крови определяли профиль интерлейкинов, используя коммерческие наборы (Merk). Воспаление снижало в крови концентрации как провоспалительных факторов (ИЛ-1 $\beta$, ИЛ-2, ИЛ-12, интреферона- $\gamma$ и хемокина МСР-1), так и противовоспалительных (ИЛ-4, ИЛ-10) цитокинов. При этом повышались уровни ФНО $\alpha$ и ИЛ-6, а также противовоспалительного цитокина ИЛ-13. Введение иммуномодуляторов полиоксидония, трекрезана и метапрота в значительной степени нормализовало уровень про- (ИЛ-1 $\beta$, ИЛ-2, ИЛ-12(p7), хемокина МСР-1, ИНФ $\alpha$ ) и противовоспалительных цитокинов (ИЛ-4, ИЛ-10). Противовоспалительный эффект препаратов связывают с нормализацией обмена цитокинов.

Ключевые слова: бронхопневмония; цитокины; иммуномодуляторы; полиоксидоний; трекрезан; метапрот.

Introduction. In recent years, immunomodulators have been actively used in bronchopulmonary inflammation, to prevent secondary immunodeficiency, disorders of energy metabolism and oxidative stress [2]. In previous studies [2, 5], the high protective effect of immunomodulators, polyoxidonium, trekrezan and metaprot in animals with experimental inflammation of bronchopulmonary tissue was shown. A number of immunopathological mechanisms that form the basis for the development of this process, mainly affecting the phagocytic immunity, have been clarified. In this work, we studied the nature of changes in the content of pro- and anti-inflammatory cytokines in the blood serum of rats in experimental bronchopulmonary inflammation and administration of immunomodulators, polyoxidonium, trekrezan and metaprot.

Material and methods. The experiments were performed on rats Wistar males weighing 200-250 g. All rats were divided into 5 groups ( $n=13-18)$ : 1) control; 2) with bronchopulmonary inflammation (BP); 3) $\mathrm{BP}+$ polyoxidonium $0.75 \mathrm{mg} / \mathrm{kg}$; 4) $\mathrm{BP}+$ trekrezan $25 \mathrm{mg} / \mathrm{kg}$; 5) $\mathrm{BP}+$ metaprot $25 \mathrm{mg} / \mathrm{kg}$. Acute bronchopneumonia was reproduced by injecting $0.1 \mathrm{ml}$ of gum turpentine into the rat trachea under ether anesthesia [2]. Immediately after the operation and further for 5 days ( 1 time per day), the test animals were in- 
Cytokine levels $(\mathrm{pg} / \mathrm{ml})$ in the serum of rats in experimental BP and treatment with immunomodulators $(M \pm m)$

\begin{tabular}{|c|c|c|c|c|c|}
\hline Cytokines & Control, $n=18$ & $\begin{array}{c}B P, \\
n=19\end{array}$ & $\begin{array}{c}\text { BP + polyoxidonium, } \\
n=13\end{array}$ & $\begin{array}{c}\text { BP + trekrezan, } \\
n=15\end{array}$ & $\begin{array}{c}\text { BP + metaprot, } \\
n=16\end{array}$ \\
\hline IL-1 $\beta$ & $0.12 \pm 0.03$ & $0.07 \pm 0.01$ & $0.35 \pm 0.04^{*} * *$ & $0.24 \pm 0.04^{*, * *}$ & $0.18 \pm 0.03^{* *}$ \\
\hline IL-2 & $0.39 \pm 0.06$ & $0.21 \pm 0.04^{*}$ & $0.58 \pm 0.05^{*, * *}$ & $0.41 \pm 0.06^{* *}$ & $0.42 \pm 0.05^{* *}$ \\
\hline $\mathrm{TNF} \alpha$ & $3.1 \pm 0.5$ & $9.8 \pm 1.2^{*}$ & $6.1 \pm 0.9^{*, * *}$ & $5.3 \pm 0.6^{*, * *}$ & $4.5 \pm 0.06^{*, * *}$ \\
\hline IL-4 & $0.16 \pm 0.03$ & $0.09 \pm 0.001 *$ & $0.26 \pm 0.05^{* *}$ & $0.47 \pm 0.05^{*, * *}$ & $0.48 \pm 0.06^{*, * *}$ \\
\hline IL-6 & $0.31 \pm 0.05$ & $1.45 \pm 0.15^{*}$ & $0.62 \pm 0.04^{*, * *}$ & $0.66 \pm 0.05^{*, * *}$ & $0.58 \pm 0.004^{*}, * *$ \\
\hline IL-10 & $0.12 \pm 0.03$ & $0.07 \pm 0.01$ & $0.51 \pm 0.07^{*, * *}$ & $0.41 \pm 0.05^{*, * *}$ & $0.26 \pm 0.04^{* * * *}$ \\
\hline IL-2(p70) & $0.34 \pm 0.07$ & $0.19 \pm 0.03$ & $0.45 \pm 0.06^{* *}$ & $0.41 \pm 0.07^{* *}$ & $0.37 \pm 0.06^{* *}$ \\
\hline IL-13 & $0.09 \pm 0.002$ & $0.28 \pm 0.04^{*}$ & $0.36 \pm 0.05^{*}$ & $0.35 \pm 0.06^{*}$ & $0.19 \pm 0.03^{*}$ \\
\hline IL-17A & $1.8 \pm 0.4$ & $2.0 \pm 0.3$ & $2.9 \pm 0.4$ & $2.4 \pm 0.5$ & $1.9 \pm 0.5$ \\
\hline INF $\gamma$ & $0.2 \pm 0.04$ & $0.14 \pm 0.02$ & $0.21 \pm 0.04$ & $0.46 \pm 0.04^{*, * *}$ & $0.45 \pm 0.05^{*} * *$ \\
\hline $\mathrm{MCP}-1$ & $2.4 \pm 0.5$ & $1.16 \pm 0.02^{*}$ & $2.9 \pm 0.04^{* *}$ & $2.8 \pm 0.03^{* *}$ & $2.3 \pm 0.5^{* *}$ \\
\hline
\end{tabular}

N o t e. ${ }^{*} p<0.05$ to the control group; ${ }^{* *} p<0.05$ to the group with bronchopneumonia (BP).

traperitoneally injected with a solution of one of the studied immunomodulators. On the $5^{\text {th }}$ day of the experiment, the rats were decapitated, blood was taken, from which serum was prepared, the serum was frozen and stored at $-20{ }^{\circ} \mathrm{C}$ until testing. The concentration of cytokines was determined by the method of proteon multiplex analysis using flow immunofluorometry [3], Bio-Rad Laboratories instrument (USA). Used commercial kits Milliplex Map Rat Citokine/Chemokine (Merk) in accordance with the manufacturer's instructions. Statistical processing of the results was performed using the standard software package Statistica for Windows 6.0.

Results and discussion. Experimental BP in rats, confirmed morphologically [2], was accompanied by significant changes in the content of cytokines in the blood serum, produced both by B- and by $\mathrm{T}_{\mathrm{x} 1}$ and $\mathrm{Th}_{\mathrm{x} 2}$ lymphocytes and other cells (Table 1). At the same time, concentrations of both pro-inflammatory (IL-1 $\beta$, IL-2, IL-12, INF- $\gamma$ and chemokine MCP-1) and anti-inflammatory factors (IL-4, IL-10) decreased in the blood. The levels of TNF $\alpha$ and IL-6, as well as the anti-inflammatory cytokine IL-13 (3 times) were elevated in the blood.

In general, experimental BP in rats contributed to the development of secondary immunodeficiency with a sharp inhibition of the immunoregulatory functions of cytokines. Thus, the content of TNF $\alpha$, which is a powerful factor of excessive proliferation and enhancement of apoptosis, an inducer of the development of not only local, but also systemic inflammation [1], increased by more than 3 times. The high severity of the systemic inflam- matory process is indicated by a 5 -fold increase in the content of IL-6, which is a "damage cytokine" and produced not only by monocytes, but also by $\mathrm{T}$ cells, macrophages, fibroblasts and endothelial cells [4]. IL-6 activates B-lymphocytes with the formation of plasma cells and antibodies [1].

In the treatment of BP with immunomodulators, the mortality rate of animals decreased significantly. Thus, the rats' survival rate with the introduction of polyoxidonium was $58 \%$, trekrezan $65 \%$ and metaprot $60 \%$ compared with $48 \%$ survival in BP rats without drug administration. The course introduction of immunomodulators significantly limited the effect of the pathological process on the content of cytokines in the blood of rats. The level of proinflammatory cytokines IL-1 $\beta$, IL-2, IL-12 (p7), as well as chemokine MCP-1 and INF $\alpha$, as well as the anti-inflammatory cytokines IL-4, IL-10, IL-13 became significantly higher, which indicates partial restoration of immunoregulatory function and even expression of cytokine-producing properties of B-cells, $\mathrm{T}_{\mathrm{x} 1}, \mathrm{Th}_{\mathrm{x} 2}$ cells of lymphocytes. The studied drugs significantly limited the cytotoxic effect of IL-6, one of the leading mediators of inflammation. Apparently, the sanogenetic mechanism of action of the studied drugs is the restoration of the production of anti-inflammatory cytokines IL-4 and IL-10.

Conclusion. Therefore, pharmacological agents used to reduce the severity of BP in rats exhibit the properties of true immunomodulators, helping to identify the protective properties of cytokines and providing a complex adaptive response of the body in severe inflammation in bronchopulmonary tissue. 


\section{References}

1. Berezhnaya NM. Cytokine regulation in pathology: rapid development and unavoidable questions. Cytokines and inflammation. 2007;2(6):26-34. (In Russ.)

2. Zarubina IV, Mokrenko EV, Bolekhan AV, Shabanov PD. Comparative anti-inflammatory and ergotropic activity of the metaprot, trekrezan and polyoxidonium and their combinations in experimental bronchopulmonary inflammation in rats. Med. Acad. J. 2016;16(3):48-50. (In Russ.)

3. Ostanin AA, Leplina OYu, Shevela EYa, et al. Evaluation of the cytokine profile in patients with severe sepsis by flow-flurometry (Bio-Plex-analysis). Cytokines and inflammation. 2004;1(3):20-27. (In Russ.)

4. Simbirtsev AS. Cytokines: a new system of defense reactions of the body. Cytokines and inflammation. 2004;1(2):16-22. (In Russ.)

5. Shabanov PD, Zarubina IV, Mokrenko EV. Pharmacology of trekrezan - a new immunomodulator and adaptogen. Obz. po klin. farmakol. i lek. terapii. 2014;12(2):12-27. (In Russ.) 